\title{
Health Physics Enrollments and Degrees Survey, 2003 Data
}

\section{Survey Universe}

The survey includes degrees granted between September 1, 2002 and August 31, 2003. Enrollment information refers to the fall term 2003. Thirty-four academic programs at 33 different institutions were included in the survey universe with all responding (100\% response rate). Several of the programs did not have any degrees awarded during the time period. Two programs included in the 2002 survey were either discontinued or out-of-scope and not included in 2003 survey.

\section{Degree Data}

Bachelor's Degrees. The number of B.S. degrees granted in 2003 by all health physics, medical health physics, and other health physics option programs increased by $37 \%$ over 2002 , reflecting the higher undergraduate enrollments during 2001 and 2002 as compared to earlier years. This was the third consecutive year with increases reported in undergraduate degrees. (See Table 1.) Health physics programs accounted for $48 \%$ of all B.S. degrees with the remaining split between medical health physics and other health physics option programs. (See Table 2.)

Graduate Degrees. Comparing 2003 to 2002 data, the number of masters' degrees decreased by 3 and the number of doctorate degrees increased by 5. (See Table 1.) The number of masters' degrees granted in 2003 was $38 \%$ below the number in 1998. Health physics programs accounted for $77 \%$ of the masters' degrees and $68 \%$ of the doctorate degrees. Most of the remaining were in medical health physics programs. (See Table 2.)

Table 1. Health Physics Degrees and Enrollments, 1998-2003

\begin{tabular}{|c|c|c|c|c|c|c|}
\hline \multirow[b]{2}{*}{ Year } & \multicolumn{3}{|c|}{ Degrees } & \multicolumn{3}{|c|}{ Enrollments } \\
\hline & B.S. & M.S. & Ph.D. & $\begin{array}{l}\text { Junior \& } \\
\text { Senior } \\
\text { Undergrad } \\
\text { Students }\end{array}$ & $\begin{array}{l}\text { Master's } \\
\text { Graduate } \\
\text { Students }\end{array}$ & $\begin{array}{c}\text { PhD } \\
\text { Graduate } \\
\text { Students }\end{array}$ \\
\hline 2003 & 56 & 73 & 25 & 153 & 264 & 88 \\
\hline 2002 & 41 & 76 & 20 & 104 & 227 & 94 \\
\hline 2001 & 37 & 71 & 23 & 117 & 207 & 123 \\
\hline 2000 & 33 & 79 & 24 & 72 & 213 & 108 \\
\hline 1999 & 55 & 115 & 22 & 82 & 273 & 123 \\
\hline 1998 & 51 & 118 & 26 & 89 & 325 & 127 \\
\hline
\end{tabular}

The data reflect the update of the survey universe of health physics programs that was done in 2002 . The undergraduate enrollments reported last year for 2002 were changed from 114 to 104 based on a correction provided in this year's survey.

Table 2. Health Physics Degrees by Curriculum, 2003

\begin{tabular}{lrrr}
\multicolumn{1}{c}{ Curriculum } & B.S. & M.S. & Ph.D. \\
\hline Health Physics Program & 27 & 56 & 17 \\
Medical Health Physics & 13 & 16 & 5 \\
Other Health Physics Option & 16 & 1 & 3
\end{tabular}




\section{Enrollments and Short-Term Outlook for Degree Trends}

The enrollment of junior and senior undergraduate students increased by $47 \%$ between 2002 and 2003 . (See Table 1.) In 2001 and 2002, the undergraduate enrollments were considerably higher than in the preceding three years. This enrollment trend indicates that the number of bachelor's degrees are likely to remain approximately the same in 2004 but should increase in 2005.

The enrollment of masters' level graduate students increased 16\% in the fall 2003 versus the fall of 2002 . This is almost 28\% higher than the master's level enrollment in 2001. These enrollment increases suggest that the number of masters' degrees will also increase over the next two to three years.

Between 1998 and 2000, doctorate level enrollments decreased and then increased in 2001. However, doctorate level enrollments decreased in 2002 and again in 2003. Given the overall decline in doctorate enrollments over the last six years, it is likely that the number of doctorate degrees will also decline somewhat over the next few years.

\section{U.S. Citizenship, Gender, and Race/Ethnicity Data}

Among B.S. degree graduates, 1 was reported as a non-U.S. citizen; 10 of the 52 reported (19\%) were females; and of the 51 reported as U.S. citizens, 8 (16\%) were non-Caucasian. (See Table 3.)

Among M.S. degree graduates, 7 were reported as non-U.S. citizens; 24 of the 69 reported (35\%) were females; and of the 62 reported as U.S. citizens, 10 (16\%) were non-Caucasian.

Among the Ph.D. degree graduates, 11 were reported as non-U.S. citizens; 8 of the 22 reported (36\%) were female; and of the 11 reported as U.S. citizens, 4 (36\%) were non-Caucasian.

Table 3. U.S. Citizenship, Gender, and Race/Ethnicity Data, 2003

\begin{tabular}{|c|c|c|c|c|c|c|c|c|}
\hline & $\begin{array}{c}\text { Non U.S. } \\
\text { Citizen }\end{array}$ & $\begin{array}{c}\text { African } \\
\text { American } \\
\end{array}$ & $\begin{array}{c}\text { Asian/ } \\
\text { Pacific } \\
\text { Islander } \\
\text { American } \\
\end{array}$ & $\begin{array}{l}\text { Caucasian } \\
\text { American }\end{array}$ & $\begin{array}{c}\text { Hispanic } \\
\text { American } \\
\end{array}$ & $\begin{array}{c}\text { Native } \\
\text { American } \\
\end{array}$ & $\begin{array}{c}\text { Other } \\
\text { American } \\
\end{array}$ & $\begin{array}{c}\text { Not } \\
\text { Reported }\end{array}$ \\
\hline \multicolumn{9}{|l|}{ B.S. Degree } \\
\hline$\overline{\text { Female }}$ & 0 & 0 & 0 & 10 & 0 & 0 & 0 & 0 \\
\hline Male & 1 & 3 & 1 & 33 & 3 & 1 & 0 & 0 \\
\hline Not reported & 0 & 0 & 0 & 0 & 0 & 0 & 0 & 4 \\
\hline \multicolumn{9}{|l|}{ M.S. Degree } \\
\hline Female & 1 & 0 & 2 & 19 & 1 & 0 & 1 & 0 \\
\hline Male & 6 & 0 & 6 & 33 & 0 & 0 & 0 & 0 \\
\hline Not reported & 0 & 0 & 0 & 0 & 0 & 0 & 0 & 4 \\
\hline \multicolumn{9}{|l|}{ Ph.D. Degree } \\
\hline Female & 5 & 0 & 0 & 3 & 0 & 0 & 0 & 0 \\
\hline Male & 6 & 0 & 1 & 4 & 0 & 0 & 3 & 0 \\
\hline Not reported & 0 & 0 & 0 & 0 & 0 & 0 & 0 & 3 \\
\hline
\end{tabular}


Table 4. Health Physics Degrees by Academic Institution, 2003

\begin{tabular}{|c|c|c|c|c|c|c|}
\hline \multicolumn{2}{|c|}{$\begin{array}{l}\text { DOE NEST F\&S Status } \\
\text { as of March } 2004\end{array}$} & \multirow[b]{2}{*}{ Name of Institution } & \multirow[b]{2}{*}{$\underline{\text { State }}$} & \multicolumn{3}{|c|}{$\begin{array}{c}\text { Degrees, September 1, } 2002 \\
\text { August 31, } 2003\end{array}$} \\
\hline Fellowship & Scholarship & & & B.S. & M.S. & Ph.D. \\
\hline & & San Diego State University & $\mathrm{CA}$ & 0 & 2 & 0 \\
\hline \multirow[t]{2}{*}{ Yes } & Yes & Colorado State University & $\mathrm{CO}$ & 0 & 0 & 2 \\
\hline & & Georgetown University & DC & 0 & 2 & 0 \\
\hline Yes & Yes & University of Florida & $\mathrm{FL}$ & 0 & 4 & 3 \\
\hline Yes & Yes & Georgia Institute of Technology & GA & 0 & 10 & 0 \\
\hline \multirow[t]{3}{*}{ Yes } & Yes & Idaho State University & ID & 1 & 3 & 1 \\
\hline & & Illinois Institute of Technology & IL & 0 & 6 & 0 \\
\hline & & University of Illinois at Urbana-Champaign & IL & 4 & 1 & 1 \\
\hline \multirow[t]{2}{*}{ Yes } & Yes & Purdue University & IN & 2 & 0 & 1 \\
\hline & & Louisiana State University & LA & 0 & 6 & 0 \\
\hline Yes & Yes & Massachusetts Institute of Technology & MA & 0 & 1 & 0 \\
\hline \multirow[t]{2}{*}{ Yes } & Yes & University of Massachusetts, Lowell & MA & 0 & 5 & 5 \\
\hline & & University of Maine & ME & 2 & 0 & 0 \\
\hline Yes & Yes & University of Michigan, Ann Arbor & MI & 3 & 3 & 1 \\
\hline \multirow[t]{3}{*}{ Yes } & Yes & University of Missouri, Columbia & MO & 0 & 4 & 1 \\
\hline & & University of Missouri, Rolla & MO & 0 & 0 & 0 \\
\hline & & Thomas Edison State College & NJ & 14 & 0 & 0 \\
\hline \multirow[t]{3}{*}{ Yes } & Yes & University of New Mexico & NM & 0 & 0 & 0 \\
\hline & & University of Nevada, Las Vegas & NV & 3 & 3 & 0 \\
\hline & & Rensselaer Polytechnic Institute & NY & 4 & 1 & 1 \\
\hline \multirow[t]{3}{*}{ Yes } & Yes & Ohio State University & $\mathrm{OH}$ & 0 & 2 & 0 \\
\hline & & University of Cincinnati (Engineering) & $\mathrm{OH}$ & 0 & 3 & 1 \\
\hline & & University of Cincinnati (Radiology) & $\mathrm{OH}$ & 0 & 0 & 0 \\
\hline \multirow[t]{4}{*}{ Yes } & Yes & Oregon State University & OR & 5 & 5 & 0 \\
\hline & Yes & Bloomsburg University of Pennsylvania & PA & 4 & 0 & 0 \\
\hline & & Dickinson College & PA & 1 & 0 & 0 \\
\hline & & University of Pittsburgh & PA & 0 & 0 & 0 \\
\hline \multirow[t]{2}{*}{ Yes } & Yes & Clemson University & SC & 0 & 3 & 1 \\
\hline & & Francis Marion University & SC & 1 & 0 & 0 \\
\hline Yes & Yes & University of Tennessee, Knoxville & $\mathrm{TN}$ & 6 & 2 & 0 \\
\hline \multirow[t]{9}{*}{ Yes } & Yes & Texas A\&M University, College Station & TX & 6 & 6 & 4 \\
\hline & & University of Texas, Austin & $\mathrm{TX}$ & 0 & 0 & 0 \\
\hline & & University of Utah & UT & 0 & 1 & 3 \\
\hline & & Washington State University Tri-Cities & WA & 0 & 0 & 0 \\
\hline & & TOTALS: & & 56 & 73 & 25 \\
\hline & & By Curriculum: & & & & \\
\hline & & Health Physics Program & & 27 & 56 & 17 \\
\hline & & Medical Health Physics & & 13 & 16 & 5 \\
\hline & & Other Health Physics Option & & 16 & 1 & 3 \\
\hline
\end{tabular}


Prepared by: Science and Engineering Education, Oak Ridge Institute for Science and Education, March 2004.

This document describes activities performed under contract number DE-AC05-000R22750 between the U.S. Department of Energy and Oak Ridge Associated Universities.

All opinions expressed in this report are the author's and do not necessarily reflect policies and view of the U.S. Department of Energy or the Oak Ridge Institute for Science and Education.

The Oak Ridge Institute for Science and Education (ORISE) is a U.S. Department of Energy facility focusing on scientific initiatives to research health risks from occupational hazards, assess environmental cleanup, respond to radiation medical emergencies, support national security and emergency preparedness, and educate the next generation of scientists. ORISE is managed by Oak Ridge Associated Universities. 